\title{
Service Innovation of 3/2 Star Hotel in Bandung*
}

\author{
Yuliani Dwi Lestari ${ }^{1}$, M. I. Laode ${ }^{2}$ \\ Received: May 21, 2018 Revised: July 20, 2018 Accepted: July 30, 2018
}

\begin{abstract}
The growth of Bandung's tourism industry has had a massive impact on the hotel sector. Most tourists visiting Bandung are domestic tourists and tend to be modest spenders fitting the profile of a mid-market $(2 / 3 \mathrm{star})$ hotel guest. As competition has increased mid-market hotels have come under pressure from upmarket $(4 / 5 \mathrm{star})$ and budget hotels committed to cutting prices. There is also competition with the midmarket hotel sector, which means that the $2 / 3$ star hotels have to keep innovating in order to remain competitive. This study uses the Service Quality framework to describe customer expectations and identify gaps in hotel services. A questionnaire survey of 105 local tourists who had stayed in 2/3 star hotels in Bandung showed that the most important dimension is responsiveness, following by reliability, assurance, tangibles and empathy. Thus we conclude that local tourists' primary expectations are that hotels will deliver the service they have promised, be responsive to guests' needs and comply with service standards. Furthermore, these findings validate the earlier prediction that comparing $2 / 3$ star hotel with $5 / 4$ start hotel, the customers are having preliminary knowledge on facilities limitation and friendliness. Tourists using $2 / 3$ star hotels tend to be prepared to accept limited facilities and less friendly staff service.
\end{abstract}

Keywords: 3/2 Star-Hotel, Service Quality, Hospitality, Service Innovation, Indonesia.

JEL Classification Code: M10, M31, L83, O35.

\section{Introduction}

Bandung is one of several cities in Indonesia with a tourism industry that is developing well. This is demonstrated by the growth in the number of businesses involved in the sector. Many recreational area and tourist

* The paper was presented initially at 2018 International Conference on Business and Economics (ICBE2018) and the 14th International Conference of KODISA that was held in Seoul, South Korea, June 25-27, 2018. The paper has been recognized as one of Best Paper Awards at ICBE2018 conference. This paper is a substantially revised and expanded version of the paper presented at ICBE2018 conference. The authors have taken into account all the comments of Editors, Session Chairs and Reviewers in the revised manuscript. The authors greatly appreciate Editors, Session Chairs and Reviewers for their valuable comments, interest in and support of this research.

1 First Author and Corresponding Author. Professor, School of Business and Management, Institut Teknologi Bandung, Indonesia [Postal Address: JI. Ganesha No.10, Lb. Siliwangi, Coblong, Kota Bandung, Jawa Barat 40132, Indonesia] Email: yuliani.dwi@sbm-itb.ac.id

2. Professor, School of Business and Management, Institut Teknologi Bandung, Kota Bandung, Indonesia spots around Bandung have been developed. In addition a lot of factory outlets and restaurants have also been developed in the past 10 years. Badan Pusat Statistik (BPS) kota Bandung data indicate that at the time of writing there were 426 restaurants registered in Bandung, up from just 247 in 2005 an almost 200 percent growth over the last 9 years. Growth in tourism and creative industry following the increase of tourist visits that happen almost every year. BPS kota Bandung recorded 1,928,250 tourists visited Bandung in 2005. This number had almost doubled by 2011 when there were 4,070,072 tourist visits and in 2014 there were $4,418,781$ tourist visits. Infrastructure and technological developments, as well as economic growth, have stimulated the growth of Bandung's tourism industry. The opening of the Cipularang highway, which connects Bandung and Jakarta, has made it easier for people in Jakarta to visit Bandung. The ease with which the Internet allows people to access travel information encourages people to travel and has helped to make Bandung a travel destination. Economic growth has increased the numbers of middle- and upperclass people in Indonesia. These three conditions have produced an increase in the number of tourists coming to Bandung. 
Hotels in Bandung are divided into two types, star and non-star hotels. There are five grades of star hotel (1-5 stars) and three grades of non-star hotel or jasmine (melati) hotels. BPS kota Bandung indicates that at the time of writing there was a grand total of 382 star and non-star hotels. Hotels are rated by the Tourism Business Certifications Institution (LSU Bidang Pariwisata), an independent institution appointed by the Indonesian government. Every hotel is rated according to standards specified in the Ministry of Tourism and Creative Economy's Regulation Nomor PM. 53/HM.001/ MPEK/2013.

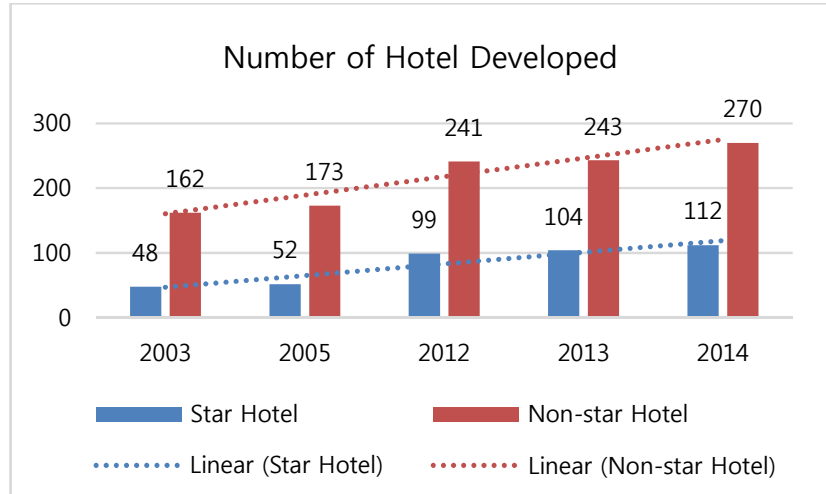

Source: Analysis.

Figure 1. Number of Hotel Developed in Bandung

The challenge of hotel industry in Bandung is not only the new player in this industry. A changing technological environment and changing competition, social and economic conditions have shifted customer behavior. Nowadays, people can easily compare prices using their smartphone and the Internet and this has led to fierce competition. Herman Muchtar, Chairman of PHRI West Java has stated that hoteliers have no choice but to cut room prices (Susanti, 2015). Many of the groups currently investing in Bandung's hospitality industry are investing in low star hotels. There are reasons why some investment groups choose to develop relatively cheap budget hotels. A recent survey by Market Metrix, a global hospitality industry consultancy, indicated that location and price are the two main determinants of a customer's choice of hotel: $30.2 \%$ respondents specified location as the main factor in their choice whilst $15.7 \%$ specified price (Dewi Magazine, 2015). This suggests that it is better to develop many simple, budget hotels in a several strategic locations rather than one luxury hotel.

The aim of this research was to identify factors that affect customers' choice of two- and three-star hotels in Bandung. The same method was used as in previous research on four- and five-star hotels in Bandung (Saputra, 2014). The integrated SERVQUAL framework was used to identify factors affecting customers' choices. The results provide hoteliers in Bandung with insight into future changes in the market environment.

\section{Literature Review}

Both product and service companies understand that it is vital that customers have a good experience of their product or service. Products and services are often the first thing that customers see of company, so they should make an impact (Slack et al., 2010). As service companies it is especially important for hotels to focus on ensuring customer satisfaction and offering a good customer experience. Brett Shockley, Senior Vice President and Chief Technology Officer at Avaya (blog.clientheartbeat.com) has written that the customer experience offers a way to increase loyalty and retention. Offering a good customer experience can generate good publicity and help to promote the hotel because guests will share their experience with friends and families. Good experiences can be created through good service design and by offering good products. The objective of good design, whether of products or services, is to satisfy customers by meeting their actual or anticipated needs and expectations. Doing this enhances the competitiveness of an organization (Slack et al., 2010) and during the hard times it is the more competitive organizations that tend to endure.

Just as with other profit-making organizations, product and service design is critical to hotels' ability to provide a good customer experience. As stated above, customer satisfaction with a produce or service leads to loyalty and retention. A Kenyan study (Mbuthia et al., 2013) provided evidence of a relationship between guest experience and perceived quality to guest' satisfaction. Markovic et al. (2010) found that an association between guest satisfaction and guest loyalty in Croatia, with the most satisfied factor for guest in the research is reception department. Markovic and Jankovic (2013) found that the most important factors in hotel guests' satisfaction were a good location, easy withinhotel navigation, perceived safety and security, courteous hotel staff, cleanliness and tidiness, perception that the hotel had guests' best interests at heart, quality of service typical for the category of hotel and staff willingness to help. Sapari et al. (2012) concluded from their study of eco-tourism and resort sites in Langkawi, Malaysia that good facilities are an important factor in guest satisfaction. A study of three- and four-star hotels in Malaysia (Kim-Soon et al., 2014) noted that satisfied guests were more likely to return and to recommend the hotel to other potential customers. 
Designing a service is different from designing a product. Designing services is challenging because services often have unique characteristics (Heizer \& Render, 2011). Most services required its customer during designing and deliver the service. The object of service design is to put together a service which meets, or even exceeds, customer expectations. The service must also be within the organization's operational capability and be delivered at a reasonable cost (Slack et al., 2010). Customer involvement in service design is required to devise an appealing service. In the case of hotel service it is necessary to understand what factors lead to guest satisfaction and dissatisfaction. SERVQUAL is one of the frameworks that can be used to determine the factors that are important to guests' satisfaction. SERVQUAL has been used for many purpose in hotel research: determining guests' level of satisfaction with hotel services, assessing perceptions of quality, distinguishing between the satisfaction levels of three- and four-star hotels, determining which factors affect guests' decision to recommend or revisit, as well as choice decisions and many other purposes. The following part provides the list of literatures in this study.

Parasuraman et al. (1988) determined SERVQUAL in five dimensions:

1. Tangibles: Physical facilities, equipment, and appearance of personnel.

2. Reliability: Ability to perform the promised service dependably and accurately.

3. Responsiveness: Willingness to help customers and provide prompt service.

4. Assurance: Knowledge and courtesy of employees and their ability to inspire trust and confidence.

5. Empathy: Caring, personal attention to customers.

Table 1 lists the SERVQUAL dimensions and factors used in this study. In total, this study used 16 factors derived from various references.

Table 1. SERVQUAL Dimensions and Subfactors

\begin{tabular}{|c|c|c|c|}
\hline Dimensions & Factors & Sub Factors & References \\
\hline \multirow[t]{4}{*}{ 1. Tangible } & 1.1 Location & $\begin{array}{l}\text { Location can affect hotel occupancy rate. In the hospitality } \\
\text { business a hotel's income is influenced by location. } \\
\text { The sub-factors include in location are proximity to a place } \\
\text { of interest (mall; factory outlet; amusement park) or } \\
\text { business area; ease of access; Safety and security. }\end{array}$ & $\begin{array}{l}\text { Chu and Choi (1999), Nguyen } \\
\text { et al. (2015), Markovic and } \\
\text { Jankovic (2013), Dortyol et al. } \\
\text { (2014), Ho et al. (2013) }\end{array}$ \\
\hline & $\begin{array}{l}1.2 \text { Facilities and } \\
\text { Equipment }\end{array}$ & $\begin{array}{l}\text { Facilities and equipment can determine whether guests' } \\
\text { have a pleasurable experience because they are critical to } \\
\text { whether guests' needs and expectations are fulfilled. } \\
\text { The sub-factors are Room size; Modern equipment, } \\
\text { maintenance of facilities; Appearance of physical facilities; } \\
\text { Room cleanliness. }\end{array}$ & $\begin{array}{l}\text { Markovic and Jankovic (2013), } \\
\text { Kim-Soon et al. (2014), Dortyol } \\
\text { et al. (2014), Bucak et al. } \\
\text { (2013), Ho et al. (2013), } \\
\text { Juwaheer (2004), Nguyen et al. } \\
\text { (2014), Rauch et al. (2015) }\end{array}$ \\
\hline & $\begin{array}{l}1.3 \text { Restaurant } \\
\text { ambience; Food and } \\
\text { beverages }\end{array}$ & $\begin{array}{l}\text { A restaurant with a good ambience and high quality food } \\
\text { and beverages can be an added-value feature for a hotel. } \\
\text { The sub-factors are Seating arrangement in the restaurant; } \\
\text { Healthiness of food and beverages; Hygiene; Variety of } \\
\text { breakfast menu. }\end{array}$ & $\begin{array}{l}\text { Juwaheer (2004), Nguyen et al. } \\
\text { (2015), Dortyol et al. (2014), } \\
\text { Chu and Choi (1999), Rauch et } \\
\text { al. (2015) }\end{array}$ \\
\hline & 1.4 Other Amenities & $\begin{array}{l}\text { Other supporting facilities are needed to ensure guests } \\
\text { enjoy their stay in a hotel and so these amenities can be a } \\
\text { determinant of hotels' service quality. } \\
\text { The sub-factors are Functioning of facilities; Availability of } \\
\text { wi-fi; Additional facilities; Cleanliness and hygiene; Parking } \\
\text { space. }\end{array}$ & $\begin{array}{l}\text { Dortyol et al. (2014), Mbuthia et } \\
\text { al. (2013), Ho et al. (2013) }\end{array}$ \\
\hline \multirow[t]{2}{*}{ 2. Reliability } & $\begin{array}{l}2.1 \text { Service } \\
\text { Efficiency }\end{array}$ & $\begin{array}{l}\text { The time taken to perform a service affects how customers } \\
\text { assess that service. } \\
\text { The sub-factors are Prompt; and Efficient service. }\end{array}$ & $\begin{array}{l}\text { Markovic and Jankovic (2013), } \\
\text { Bucak (2014), Mbuthia et al. } \\
\text { (2013), Kim-Soon et al. (2014), } \\
\text { Dortyol et al. (2014), Nguyen et } \\
\text { al. (2015), Chu and Choi } \\
\text { (2000), Rauch et al. (2015) }\end{array}$ \\
\hline & $\begin{array}{l}2.2 \text { Information } \\
\text { Reliability }\end{array}$ & $\begin{array}{l}\text { The information quality of being trustworthy or of performing } \\
\text { consistently well. } \\
\text { The sub-factors are Ease with which information can be } \\
\text { obtained; Accuracy of signs and directions. }\end{array}$ & $\begin{array}{l}\text { Mbuthia, et al. (2013), } \\
\text { Markovic and Jankovic (2013), } \\
\text { Dortyol et al. (2013) }\end{array}$ \\
\hline
\end{tabular}




\begin{tabular}{|c|c|c|c|}
\hline & $\begin{array}{l}2.3 \text { Service } \\
\text { Accuracy }\end{array}$ & $\begin{array}{l}\text { Service accuracy refers to whether or not a hotel fulfils its } \\
\text { obligations and delivers the promised service features. } \\
\text { The sub-factors are Error-free services on reservation } \\
\text { system; Issuing of bills. }\end{array}$ & $\begin{array}{l}\text { Mbuthia, et al. (2013), } \\
\text { Markovic and Jankovic (2013), } \\
\text { Dortyol et al. (2013) } \\
\text { Chu and Choi (2000), Nguyen } \\
\text { et al. (2015), Mbuthia et al. } \\
\text { (2013), Juwaheer (2004), } \\
\text { Markovic and Jankovic (2013), } \\
\text { Ho et al. (2013), Dortyol et al. } \\
\text { (2014), Rauch et al. (2015) }\end{array}$ \\
\hline \multirow[t]{3}{*}{ 3. Responsiveness } & $\begin{array}{l}3.1 \text { Handling of } \\
\text { Problems and } \\
\text { Complaints }\end{array}$ & $\begin{array}{l}\text { Problems and complaints may occasionally arise. How } \\
\text { these are handled will affect guests' judgment of the hotel's } \\
\text { service. } \\
\text { The sub-factors are employee's ability to handle customer } \\
\text { complaints; accuracy on solving the problem. }\end{array}$ & $\begin{array}{l}\text { Dortyol et al. (2014), Nguyen et } \\
\text { al. (2015), Juwaheer (2004), } \\
\text { Bucak (2014), Markovic and } \\
\text { Jankovic (2013) }\end{array}$ \\
\hline & $\begin{array}{l}3.2 \text { Employee } \\
\text { Responsiveness to } \\
\text { Guests }\end{array}$ & $\begin{array}{l}\text { Customer-facing employees need to respond quickly to } \\
\text { guests' requests and ensure they receive a satisfactory } \\
\text { service. } \\
\text { The sub-factors are Availability of employees; } \\
\text { Employees' responsiveness to complaints. }\end{array}$ & $\begin{array}{l}\text { Dortyol et al. (2014), Markovic } \\
\text { and Jankovic (2013), Mbuthia et } \\
\text { al. (2013), Ho et al. (2013), } \\
\text { Bucak (2014), Nguyen et al. } \\
\text { (2015), Juwaheer (2004) }\end{array}$ \\
\hline & $\begin{array}{l}3.3 \text { Employee } \\
\text { Proactivity }\end{array}$ & $\begin{array}{l}\text { If employees take a proactive approach to customer service } \\
\text { it creates a good impression as it suggests the hotel in } \\
\text { sincere about helping guests and making their stay as } \\
\text { comfortable as possible. } \\
\text { The sub-factors are Employees' willingness; } \\
\text { Rapidity of employees' response to guests. }\end{array}$ & $\begin{array}{l}\text { Kim-Soon et al. (2014), } \\
\text { Markovic and Jankovic (2013), } \\
\text { Juwaheer (2004), Ho et al. } \\
\text { (2013), Nguyen et al. (2015), } \\
\text { Chu and Choi (2000) }\end{array}$ \\
\hline \multirow[t]{3}{*}{ 4. Assurance } & $\begin{array}{l}\text { 4.1 Employee } \\
\text { Appearance \& } \\
\text { Attitude }\end{array}$ & $\begin{array}{l}\text { Employee's self-presentation can influence guests' } \\
\text { confidence in a hotel. } \\
\text { The sub-factors are Cleanliness and neatness of } \\
\text { employees' dress; Employees' manner of communication; } \\
\text { Employees' ability to instill confidence }\end{array}$ & $\begin{array}{l}\text { Markovic and Jankovic (2013), } \\
\text { Kim-Soon et al. (2014), } \\
\text { Juwaheer (2004), Dortyol et al. } \\
\text { (2014), Mbuthia et al. (2013), } \\
\text { Ho et al. (2013), Bucak } \\
\text { (2014), Chu and Choi (2000), } \\
\text { Nguyen et al. (2015) } \\
\end{array}$ \\
\hline & $\begin{array}{l}4.2 \text { Employee Skill } \\
\text { and Knowledge }\end{array}$ & $\begin{array}{l}\text { Employees are required to perform the service correctly and } \\
\text { so they need sufficient skills and knowledge to do this. } \\
\text { The sub-factors are Employees' knowledge of hotel } \\
\text { products and the surrounding area; } \\
\text { Employees' service skills. }\end{array}$ & $\begin{array}{l}\text { Dortyol et al. (2014), Juwaheer } \\
\text { (2004), Kim-Soon et al. (2014), } \\
\text { Ho et al. (2013), Nguyen et al. } \\
\text { (2015), Chu and Choi (2000), } \\
\text { Mbuthia et al. (2013) }\end{array}$ \\
\hline & $\begin{array}{l}4.3 \text { Compensation \& } \\
\text { Opening Hours }\end{array}$ & $\begin{array}{l}\text { Convenient opening hours and a good compensation policy } \\
\text { are needed. } \\
\text { The sub-factors are Convenience of opening hours; } \\
\text { Compensation policy. }\end{array}$ & $\begin{array}{l}\text { Bucak (2014), Markovic and } \\
\text { Jankovic (2013), Dortyol et al. } \\
\text { (2014) }\end{array}$ \\
\hline \multirow[t]{3}{*}{ 5. Empathy } & $\begin{array}{l}5.1 \text { Guest's Best } \\
\text { Interest and Service } \\
\text { Flexibility }\end{array}$ & $\begin{array}{l}\text { By appearing always to act in the best interests of guests } \\
\text { and providing a flexible service a hotel can create a good } \\
\text { impression. } \\
\text { The sub-factors are Hotel appears to act in guests' best } \\
\text { interest; Flexibility of service. }\end{array}$ & $\begin{array}{l}\text { Dortyol et al. (2014), Nguyen et } \\
\text { al. (2015), Juwaheer (2004), } \\
\text { Bucak (2014), Markovic and } \\
\text { Jankovic (2013) }\end{array}$ \\
\hline & $\begin{array}{l}\text { 5.2 Attention to } \\
\text { Guests }\end{array}$ & $\begin{array}{l}\text { Hotel needs to attend to guests, make them feel special and } \\
\text { ensure they feel comfortable during their stay in the hotel. } \\
\text { The sub-factors are Employees' personal attention; Hotel's } \\
\text { personal attention. }\end{array}$ & $\begin{array}{l}\text { Kim-Soon et al. (2014), Ho et al. } \\
\text { (2013), Markovic and Jankovic } \\
(2013) \text {, Dortyol et al. (2014), } \\
\text { Bucak (2014), Nguyen et al. } \\
\text { (2015) }\end{array}$ \\
\hline & $\begin{array}{l}5.3 \text { Understanding of } \\
\text { Guests }\end{array}$ & $\begin{array}{l}\text { Hotels need to have a good understanding of guests' needs } \\
\text { if guests are to get a good impression of the hotel's } \\
\text { services. } \\
\text { The sub-factors are Understanding of guests' needs; } \\
\text { Special attention to guests. }\end{array}$ & $\begin{array}{l}\text { Nguyen et al. (2015), Kim-Soon } \\
\text { et al. (2014), Markovic and } \\
\text { Jankovic (2013), Mbuthia et al. } \\
\text { (2013) }\end{array}$ \\
\hline
\end{tabular}


A questionnaire based on the factors described in Table 1 was designed. Responses were given using a six-point Likert scale $(1=$ not important to $6=$ extremely important $)$. Respondents to the questionnaire were required to meet the following criteria:

1. Have visited Bandung (purpose of visit not relevant);

2. Have stayed in a two- or three-star hotel before (location not relevant);

3. Aged at least 15 years old.

\section{Research Method and Results}

This section describes the preliminary psychometric analysis. Questionnaire items with Cronbach's alpha values around .70 can be considered sufficiently reliable enough to be included in the data. Table 2 below shows the Cronbach's alpha values for all items and dimensions.

Table 2. Cronbach's Alpha Value of The Data

\begin{tabular}{|l|c|}
\hline \multicolumn{1}{|c|}{ Dimensions } & Cronbach's Alpha $(\boldsymbol{\alpha})$ \\
\hline Tangible & 0,648 \\
\hline Reliability & 0,772 \\
\hline Responsiveness & 0,828 \\
\hline Assurance & 0,831 \\
\hline Empathy & 0,790 \\
\hline Data Combined Alpha $(\alpha)$ Value & 0,912 \\
\hline
\end{tabular}

It can been seen in Table 2 that the Tangibles dimension has a Cronbach's alpha of .648 whereas the other dimensions have alpha values above .70; nevertheless the Tangible dimension can be considered reliable as previous studies (Chu \& Choi, 1999; Juwaheer, 2004; Nguyen et al., 2015; Kim-Soon et al., 2014) have states that factors with alpha values above .60 can be considered sufficiently reliable. We can conclude from the reliability statistics (Cronbach's alpha) that the survey data are sufficiently reliable to be used in modeling.

Item-total correlations provide an indication of the validity of data. Table 3 below presents item-total correlations for all items. From the previous chapter we know that items can be considered valid if they have an item-total correlation of above .30, or in some cases above .25 (Azwar, 1999). Thus we can conclude from the data in Table 3 that all the items are valid and can be used in the model.
Table 3. Item to Total Correlation Value

\begin{tabular}{|c|l|c|}
\hline No. & \multicolumn{1}{|c|}{ Factors } & $\begin{array}{c}\text { Item to Total } \\
\text { Correlation } \\
\text { Value }\end{array}$ \\
\hline 1. & Hotel Location (T1) & 0,275 \\
\hline 2. & Hotel Facilities and Equipments (T2) & 0,606 \\
\hline 3. & $\begin{array}{l}\text { Restaurant's Ambience, Food and } \\
\text { Beverage (T3) }\end{array}$ & 0,512 \\
\hline 4. & Other Amenities (T4) & 0,621 \\
\hline 5. & Service Time Efficiency (REL1) & 0,607 \\
\hline 6. & Hotel Information Reliability (REL2) & 0,668 \\
\hline 7. & Hotel Service Accuracy (REL3) & 0,638 \\
\hline 8. & $\begin{array}{l}\text { Problems and Complaints Handling } \\
\text { Method (RES1) }\end{array}$ & 0,645 \\
\hline 9. & $\begin{array}{l}\text { Employee Response Toward Guest's } \\
\text { Call (RES2) }\end{array}$ & 0,719 \\
\hline 10. & Employee Proactiveness (RES3) & 0,726 \\
\hline 11. & Employee Appearance \& Attitude (ASS1) & 0,730 \\
\hline 12. & Employee Skill and Knowledge (ASS2) & 0,757 \\
\hline 13. & Compensation \& Opening Hours (ASS3) & 0,725 \\
\hline 14. & $\begin{array}{l}\text { Guest's Best Interest and Service } \\
\text { Flexibility (EMP1) }\end{array}$ & 0,635 \\
\hline 15. & Attention to Guest (EMP2) & 0,584 \\
\hline 16. & $\begin{array}{l}\text { Hotel Understanding Toward Guest } \\
\text { (EMP3) }\end{array}$ & 0,468 \\
\hline & \multicolumn{2}{|l}{} \\
\hline
\end{tabular}

The following table provides the score of each factor and sub-factor that obtained from sample response regarding hotel features. Table 4 shows that the most important dimension was Responsiveness (RES), followed by reliability (REL), Assurance (AS), Tangibles ( $T$ ) and Empathy (E). The identity of the top three dimensions indicate that local tourists' main concerns are that a hotel should, fulfill its promises, be responsive to their needs and provide the promised standard of service. These findings are unsurprising, given that local tourists already have an understanding of the limitations of facilities and services, particularly staff empathy and friendliness.

Table 5 provides more detailed analysis of each factor. The factor with the highest score was RES; the mean value of its factors was high $(>5.0)$. In descending order the scores for the RES factors were: handling of problems and complaints (RES1), employee responsiveness to guests (RES2), and employee proactivity (RES3). REL had the next highest score, with service accuracy (REL3) in first place, followed by service efficiency (REL1) and information reliability (REL2). AS was in fourth place, with employee skill and knowledge (AS2) as the most important sub-factor, followed by employee appearance and attitude (AS1) and compensation and opening hours (AS3). T was perceived as less important than the previous three dimensions, with hotel location (T1) the most important sub-factor, followed by facilities; restaurant ambience, food and beverages were 
considered to be less important. Finally all the sub-factors of E, namely guest's best interest and service flexibility, attention to guests and understanding of guests, were considered relatively unimportant (scores $<5.0$ ).

Table 4. Importance Score of SERVQUAL Dimensions

\begin{tabular}{|c|l|c|}
\hline No & \multicolumn{1}{|c|}{ Dimensions } & Total Mean \\
\hline 1. & Tangible (T) & 5,09 \\
\hline 2. & Reliability (REL) & 5,24 \\
\hline 3. & Responsiveness (RES) & 5,30 \\
\hline 4. & Assurance (A) & 5,18 \\
\hline 5. & Empathy (E) & 4,46 \\
\hline
\end{tabular}

Table 5. Importance Score of SERVQUAL Factors

\begin{tabular}{|c|l|c|}
\hline No & \multicolumn{1}{|c|}{ Factors } & Total Mean \\
\hline 1. & Hotel Location (T1) & 5,25 \\
\hline 2. & Hotel Facilities and Equipments (T2) & 5,03 \\
\hline 3. & $\begin{array}{l}\text { Restaurant's Ambience, Food and } \\
\text { Beverage (T3) }\end{array}$ & 4,82 \\
\hline 4. & Other Amenities (T4) & 5,26 \\
\hline 5. & Service Time Efficiency (REL1) & 5,31 \\
\hline 6. & Hotel Information Reliability (REL2) & 5,05 \\
\hline 7. & Hotel Service Accuracy (REL3) & 5,36 \\
\hline 8. & $\begin{array}{l}\text { Problems and Complaints Handling } \\
\text { Method (RES1) }\end{array}$ & 5,43 \\
\hline 9. & $\begin{array}{l}\text { Employee Response Toward Guest's Call } \\
\text { (RES2) }\end{array}$ & 5,30 \\
\hline 10. & Employee Proactiveness (RES3) & 5,15 \\
\hline 11. & Employee Appearance \& Attitude (AS1) & 5,21 \\
\hline 12. & Employee Skill and Knowledge (AS2) & 5,23 \\
\hline 13. & Compensation \& Opening Hours (AS3) & 5,11 \\
\hline 14. & $\begin{array}{l}\text { Guest's Best Interest and Service } \\
\text { Flexibility (E1) }\end{array}$ & 4,99 \\
\hline 15. & Attention to Guest (E2) & 4,05 \\
\hline 16. & Hotel Understanding Toward Guest (E3) & 4,36 \\
\hline
\end{tabular}

\section{Conclusion}

The aim of this study was to describe local tourists' expectations of the service in 2/3 star hotels in Bandung. The analysis revealed that they considered responsiveness the most important aspect of a hotel's service, followed by reliability, assurance, tangibles and finally empathy. These findings validate the earlier prediction that comparing $2 / 3$ star hotel with 5/4 start hotel, the customers (tourists) are having preliminary knowledge on facilities limitation and friendliness. Tourists using $2 / 3$ star hotels tend to be prepared to accept limited facilities and less friendly staff service than tourists staying in higher star hotels.

Although tangibles were considered less important than most other aspects of a $2 / 3$ star hotel's service, it is suggested that these hotels present their 'limited facilities' not as a negative feature, but as a deliberate choice, designed to ensure that the hotel meets customers' basic needs and offers value for money. It is suggested that hotels adopt a 'smart pricing' policy, offering several facilities options at different prices to accommodate differing needs.

Although empathy emerged as the least important dimension, it is suggested that hotels give staff basic training in greeting and communication skills as these skills are the basis of a responsive, reliable and assured service, and these were the three service dimensions that potential customers considered most important.

\section{References}

AbuKhalifeh, A. N., \& Som, A. P. M. (2012). Service Quality Management in Hotel Industry: A Conceptual Framework for Food and Beverage Departments. International Journal of Business and Management, 7(14), 135-141.

Anderson, D. R., Sweeney, D. J., \& Williams, T. A. (2011). Statistics For Business And Economics. Mason, $\mathrm{OH}$ : South-Western Cengage Learning.

Asdhiana, I. M. (2015). Kota Bandung Didesak Moratorium Hotel Baru, Kompas Travel, 20 Januari. Retrieved October 21, 2016 from http://travel.kompas.com/ read/2015/01/20/164300427/Kota.Bandung.Didesak. Moratorium. Hotel.Baru.

Azwar, S. (1999). Reliabilitas dan Validitas: Seri Pengukuran Psikologi, Yogyakarta, INA : Sigma Alpha.

Badan Pusat Statistik Kota Bandung (2012). Kota Bandung Dalam Angka 2011, Bandung, INA : Badan Pusat Statistik Kota Bandung.

Badan Pusat Statistik Kota Bandung (2013). Kota Bandung Dalam Angka 2012, Bandung, INA : Badan Pusat Statistik Kota Bandung.

Badan Pusat Statistik Kota Bandung (2015). Kota Bandung Dalam Angka 2015, Bandung, INA : Badan Pusat Statistik Kota Bandung.

Badan Pusat Statistik Kota Bandung (2016). Kota Bandung Dalam Angka 2016, Bandung, INA : Badan Pusat Statistik Kota Bandung.

Bucak, T. (2014). The Effect of Service Quality on Customer Satisfaction: A Research on Hotel Business. International Journal of Education and Research, 2(1), 1-12.

Burns, A. C., \& Bush, R. F. (2003). Marketing Research: Online Research Applications. Upper Saddle River, $\mathrm{NJ}$ : Pearson Education.

Chu, R. K. S., \& Choi, T. (2000). An ImportancePerformance Analysis of Hotel Selection Factors in the Hong Kong Hotel Industry: A Comparison of 
Business and Leisure Travellers. Tourism Management, 21, 363-377.

Dewi Magazine (n.d.). Apa Alasan Utama Anda Memilih Hotel? Retrieved October 21, 2017 from http://www.dewimagazine.com/news-food/apa-alasan -utama-anda-memilih-hotel-.

Dichter, A., \& Seitzman, N. (2015). Facebook and The Future of Travel, Mckinsey \& Company. Retrieved October 22, 2016 from http://www.mckinsey.com/ industries/travel-transport-and-logistics/our-insights/ facebook-and-the-future-of-travel.

Dortyol, I. T., Varinli, I., \& Kitapci, O. (2014). How Do International Tourists Perceive Hotel Quality? An Exploratory Study of Service Quality in Antalaya Tourism Region. International Journal of Contemporary Hospitality Management, 26(3), 470495.

Eraqi, M. I. (2006). Tourism Service Quality (TourServQual) in Egypt: The Viewpoints of External and Internal Customers. Benchmarking: An International Journal, 13(4), 469-492.

Farid, R. (2015). Persaingan Bisnis Hotel di Bandung Mengarah Tidak Sehat, Jurnal Bandung, 27 March. Retrieved October 22, 2016 from http://www.jurnalbandung.com/persaingan-bisnishotel-di-bandung-mengarah-tidak-sehat/.

Handriansyah, H. (2014). Bandung Miliki Potensi Besar untuk Bisnis Perhotelan, Pikiran Rakyat, 11 November. Retrieved October 22, 2016 from http://www.pikiran-rakyat.com/ekonomi/2014/11/11/ 304226/bandung-miliki-potensi-besar-untuk-bisnisperhotelan.

Hartline, M. D., Woolridge, B. R., \& Jones, K. C. (2003). Guest Perception of Hotel Quality: Determining Which Employee Groups Count Most. Cornell Hotel and Restaurant Administration Quarterly, 44(1), 4352.

Heizer, J., \& Render, B. (2011). Operation Management, Upper Saddle River, NJ : Pearson Education.

Ho, L. H., Tien, F. P., Shu, Y. F., \& Tieh, M. Y. (2013). Integration of Kano's Model and SERVQUAL for Enhancing Standard Hotel Customer Satisfaction. African Journal of Business Management, 7(23), 2257-2265.

Iriyani, B. S., Sulistiyani, W. P. \& Ulfa, Y. A. (2015). Tingkat Penghunian Kamar Hotel 2014, Jakarta, INA : Badan Pusat Statistik.

Iriyani, B. S., Sulistiyani, W. P. \& Ulfa, Y. A. (2016). Tingkat Penghunian Kamar Hotel 2015, Jakarta, INA : Badan Pusat Statistik.

Juwaheer, T. D. (2004). Exploring International Tourists' Perceptions of Hotel Operations by Using a Modified
SERVQUAL Approach: A Case Study of Mauritius. Managing Service Quality, 14(5), 350-364.

Kementrian Pariwisata (2014). Perkembangan Jumlah Perjalanan Wisatawan Nusantara, Rata-rata Perjalanan, Pengeluaran per Perjalanan Total Pengeluaran 2009-2013, Retrieved October 22, 2016 from http://www.kemenpar.go.id/userfiles/file/B_1\% 20Rekapitulasi\%20Wisnus\%202009\%20-2013(1).pdf.

Kementrian Pariwisata (2015). Perkembangan Usaha Akomodasi Menurut Klasifikasi Akomodasi, Retrieved October 22, 2016 from http://www.kemenpar.go.id/userfiles/file/PERKEMBA NGAN\%20USAHA\%20AKOMODASI\%20MENURUT \%20KLASIFIKASI\%20AKOMODASI,\%20\%20\%20\% $20 \% 20 \% 20 \% 20$.pdf.

Kim-Soon, N., Rahman, A., \& Visvalingam, L. (2014). SERVQUAL: Can It Be Used to Differentiate Guest's Perception of Service Quality of 3 Star From a 4 Star Hotel. International Business Research, 7(7), 37-47.

Kotler, P., \& Keller, K. L. (2012). Marketing Management. Upper Saddle River, NJ : Pearson Education.

Krosnick, J. A., Narayan, S., \& Smith, W. R. (1996). Satisficing in Surveys: Initial Evidence. Advances in Survey Research, 70, 29-44.

Markovic, S., \& Jankovic, S. K. (2013). Exploring The Relationship Between Service Quality And Customer Satisfaction in Croatian Hotel Industry. Tourism and Hospitality Management, 19(2), 149-164.

Markovic, S., Jankovic, S. K., \& Segaric, K. (2010). Customer Satisfaction And Customer Loyalty Measurement in Hotel Settings: An Empirical Analysis. Conference proceedings of the 20th Biennial International Congress "Tourism \& Hospitality Industry 2010: New Trends in Tourism and Hospitality Management" (pp.125-137). Faculty of Tourism and Hospitality Management, Opatija. Hrvatska, May 6-8, 2010.

Mbuthia, S., Muthoni, C., \& Muchina S. (2013). Hotel Service Quality: Perceptions and Satisfaction Among Domestic Guests in Kenya. Arabian Journal of Business Management Review, 2(8), 22-32.

Menteri Pariwisata dan Ekonomi Kreatif Republik Indonesia (2013). Peraturan Menteri Pariwisata dan Ekonomi Kreatif Republik Indonesia Nomor PM.53/HM.001/MPEK/2013 Tentang Standar Usaha Hotel, Retrieved October 22, 2016 from http://www.kemenpar.go.id/asp/detil.asp?c=38\&id=25 69.

Nguyen, H. M., Nguyen, T. H., Phan, C. A., \& Matsui, Y. (2015). Service Quality and Customer Satisfaction: A Case Study of Hotel Industry in Vietnam. Asian Social Science, 11(10), 73-85. 
Parasuraman, A., Zeithaml, V. A., \& Berry, L. L. (1988). SERVQUAL: A Multiple-Item Scale for Measuring Consumer Perceptions of Service Quality. Journal of Retailing, 64(1),12-40.

Poku, K., Zakari, M., \& Soali, A. (2013). Impact of Service Quality on Customer Loyalty in the Hotel Industry: An Empirical Study from Ghana. International Review of Management and Business Research, 2(2), 600-609.

Ramdhani, D. (2016). 2016 Bandung Targetkan 5, 6 Juta Kunjungan Wisatawan, Kompas Regional, Retrieved October 22, 2016 from http://regional.kompas.com/ read/2016/02/18/14160251/2016.Bandung.Targetkan .5.6.Juta.Kunjungan. Wisatawan.

Rao, P. S., \& Sahu, P. C. (2013). Impact of Service Quality on Customer Satisfaction in Hotel Industry. Journal of Humanities and Social Science, 18(5), 39-44.

Rauch, D. A., Collins, M. D., Nale, R. D., \& Barr, P. B. (2015), Measuring Service Quality in Mid-scale Hotels. International Journal of Contemporary Hospitality Management, 27(1), 87-106.

Santoso, S. (2006). Seri Solusi Bisnis Berbasis TI: Menggunakan SPSS untuk Statistik Multivariat, Jakarta, INA : Elex Media Komputindo.

Sapari, M. S., Shuib, A., \& Ramachandran, S. (2012). Visitors' Satisfaction Towards Service and Facilities in Kilim Karst Geoforest Park, Langkawi. Journal of Applied Economics and Business, 1(4), 25-42.
Sekaran, U. (2003). Research Methods for Business: A Skill Building Approach. New York, NY : John Wiley \& Sons.

Shrivastava, P., \& Verma, D. S. (2014). Application of Quality Function Deployment to Improve Customer Satisfaction in Hotel Industry. International Journal of Scientific \& Engineering Research, 5(6), 957-962.

Slack, N., Chambers, S. \& Johnston, R. (2010). Operations Management, Harlow, Essex : Pearson Education.

Susanti, R., (2015). Bisnis Hotel di Bandung Babak Belur, Kompas Regional, Retrieved October 22, 2016 from http://regional.kompas.com/read/2015/03/26/112154 01/Bisnis.Hotel.di.Bandung.Babak.Belur.Kamar.Dijua I.Rp.70.000.Per.Orang.

Verma, R., Plaschka, G., \& Louviere, J.J. (2002). Understanding Customer Choices: A Key to Successful Management of Hospitality Services. Cornell Hotel and Restaurant Administration Quarterly, 43(6), 15-24.

Wahyuningrum, V., Yusuf, D.G. \& Rohaeti, E. (2015). Tingkat Penghunian Kamar Hotel Jawa Barat 2014, Bandung, INA : Badan Pusat Statistik Provinsi Jawa Barat.

Wahyuningrum, V., Yusuf, D.G. \& Rohaeti, E. (2016). Tingkat Penghunian Kamar Hotel Jawa Barat 2015, Bandung, INA : Badan Pusat Statistik Provinsi Jawa Barat. 